\title{
Non-Destructive Test on Granite Powder Concrete
}

\author{
Dr. A. Arivumangai ${ }^{1}$, Dr .T. Felixkala ${ }^{2}$, Dr. S. Arivalagan ${ }^{3}$, Mrs. P. Gomathi Nagajothi ${ }^{4}$ \\ ${ }^{1}$ Assistant Professor, Department of Civil Engineering, Dr. MGR Educational and Research Institute, \\ Maduravoyal, Chennai - 95, India, Email: arivu_civil@yahoo.co.in \\ ${ }^{2}$ Dean, Department of Civil Engineering, Dr. MGR Educational and Research Institute, Maduravoyal, \\ Chennai - 95, India, Email: kalastrut@ yahoo.com \\ ${ }^{3}$ Head, Department of Civil Engineering, Dr. MGR Educational and Research Institute, Maduravoyal, \\ Chennai - 95, India, Email: arivu357@yahoo.com \\ ${ }^{4}$ Assistant Professor, Department of Civil Engineering, Dr. MGR Educational and Research Institute, \\ Maduravoyal, Chennai - 95, India, Email: gomathinagajothi@gmail.com
}

\begin{abstract}
This paper presents a definite exploratory investigation on penetrability qualities of granite powder (GP) concrete. The primary parameter researched in this investigation was M30 and M60 grades concrete with substitution of sand by GP of 0 , 25,50 and 100 and concrete as fractional supplanting with super plasticiser, fly ash, slag and silica fume. The antacid arrangement utilized for present examination is the mix of sodium hydroxide and sodium silicate arrangement. The test example was $50 \mathrm{~mm}$ (thick) x $100 \mathrm{~mm}$ (diameter) cylinder shapes heat-relieved at $60^{\circ} \mathrm{C}$ in an oven. The variety was concentrated on the examples exposed to ambient air just as oven heat relieving. non-destructive tests on cylinders with the help of rebound hammer for a time of 28, 56, 90, 180 and 365 days. The test outcomes show that the substitution of rock and incomplete substitution of admixtures display better execution.
\end{abstract}

Keywords: Schmidt hammer, Rebound hammer Test, NonDestructive test, and Qualitative strength of Concrete.

\section{INTRODUCTION}

Concrete is a versatile material of construction used globally. Unlike metals like steel, aluminium etc., which are produced in mills by employing skilled workers, concrete is prepared locally using granites, river sand, cement and water with the help of semi-skilled and unskilled workers. Sometimes in small quantities, it is obtained by mixing the ingredients described above at the site by hand. For the requirements of medium quantities and continuous supply the ingredients are mixed at the site using a machine called mixture machine. The concrete is then transported by trucks to the site. In whatever mode, the concrete is prepared it is laid in a formwork and allowed to set and harden. After a day of casting it is cured with water or by any other means to a required number of days as demanded by site condition. After 28 days the concrete hardens completely like a rock. It is then use. Compressive strength is a backbone of concrete. It is evaluated by testing representative samples cast in the form of control specimens like a cube, cylinder, and prism at required number of days. Cement is an essential material in concrete. It binds all other ingredients. However, there is a drawback in it. Its production releases $\mathrm{CO} 2[5]$ to the environment at the rate of 1 ton of it per ton of cement produced. Therefore, to prevent degradation of the environment and to achieve sustainable construction the consumption of cement has to be curtailed. This can be obtained by harnessing the wastes in the production of concrete. These cement substitutes are called supplementary cementitious materials as well as pozzolans. Normally during the hydration of cement calcium hydroxide is released as a by-product. It is an unstable compound and tries to leave the body mass of concrete leaving pores in it through which atmospheric agent like oxygen and moisture ingress into it and attack steel reinforcement thus causing its corrosion by an electrochemical process. As a result of this concrete degrades and suffers a loss in its durability. This deterioration of concrete can be prevented by adding industrial wastes like fly ash, silica fume, marble powder, and ground granulated blast furnace slag (GGBFS), etc[4]. These wastes react with calcium hydroxide and convert it into $\mathrm{C}-\mathrm{S}-\mathrm{H}$ gel which is beneficial to concrete adding strength to it. Another issue affecting the environment is river sand. Continuous use of this material as a fine aggregate in concrete causes strain in the environment due to its depletion, thus affecting the sustainability in construction. This problem could be solved by replacing the river sand partially with industrial waste such as granite powder. 


\section{EXPERIMENTAL DETAILS}

\subsection{Materials}

The following materials are used as part of this experimental study.

\subsubsection{Cement}

In the current work, the cement was used is OPC of 53-grade. In Compliance with the fineness modulus of cement was measured as per IS code.

\subsubsection{Fine aggregate}

The normal river sand was used in preparing the concrete mixes and specific gravity of the sand was found to be 2.33 . The sand used was confined to zone 3 .

\subsubsection{Coarse aggregate}

Granite stone with the size of $10-20 \mathrm{~mm}$ was the coarse aggregate used in the current study. As per sieve analysis, size of $19 \mathrm{~mm}$ sieve found successful with 99 percent.

\subsubsection{Water}

Drinking water was used for mixing concrete since normal water may have impurities which may impact the strength and other properties of concrete.

\subsubsection{Granite powder}

Granite belongs to igneous rock family. Granite powder obtained from the polishing units and the properties were found. Since the granite powder was fine, hydrometer analysis was carried out on the powder to determine the particle size distribution.

\subsubsection{Admixture}

The partial replacement of cement using mineral and chemical admixtures like Silica fume, fly ash, slag (GGBFS) and Superplastciser.

\subsection{Mixing, Demoulding and Curing}

Thorough mixing and adequate curing are most essential for achieving a good concrete. In the laboratory, the concrete was hand mixed. The mixing time was kept to about 3-4 min for normal concrete. Generally, the demoulding was done 24 hours of casting. Potable water was used for curing all the concretes and was kept in moist environment immediately after the initial set and before the demoulding

\section{EXPERIMENTAL PROCEDURE}

Sample specimens of cylinder is shown in Figure.1. The cylinders were subjected to Schmidt hammer test [1][2] to ascertain their strength. Readings were collected at 28 days, 56 days, 90 days, 180 days and 365 days for M30 concrete and M60 concretes. It was only a qualitative test to determine the integrity of concrete, i.e., whether there are voids or cracks in concrete.

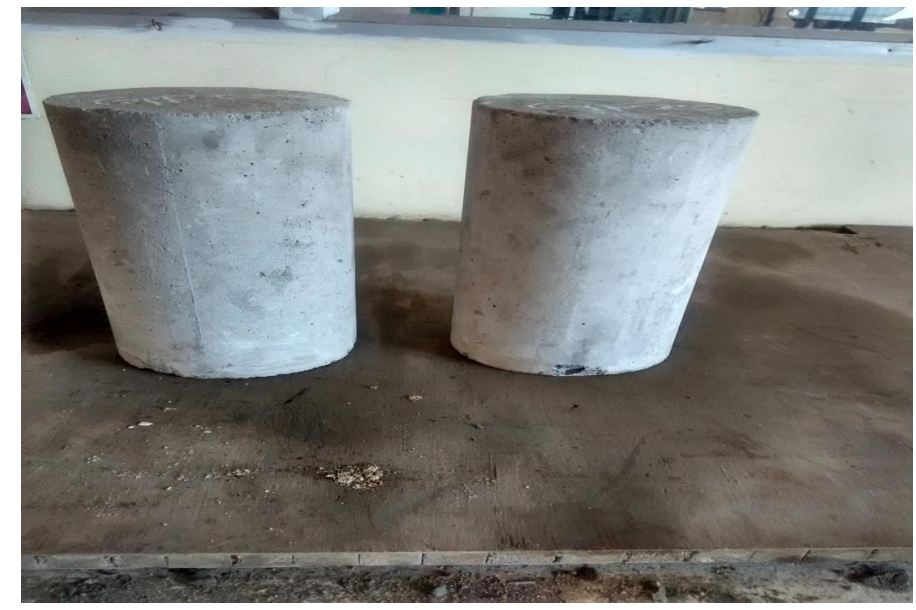

Figure 1: Sample of Specimens (cylinder) for Rebound Hammer Test

\section{RESULTS AND DISCUSSION}

The strength of various grades of concrete was assessed qualitatively by conducting non-destructive tests on cylinders with the help of rebound hammer. Results obtained are given in Table. 1 and Figure. 2 for M30 concrete and in Table 2 and Figure 3 for M60 concrete. Accordingly, in the case of M30 concrete the normal concrete (CC) with sand as fine aggregate and without any admixture was estimated to attain a strength of $33 \mathrm{MPa}$ at 28 days. The strength of the same grade of concrete with only granite powder as fine aggregate and without any admixture (NA100) was estimated to achieve $35 \mathrm{MPa}$, an increase of $6.06 \%$ over conventional concrete with sand. Similar enhancement in estimated strength was observed for other ages like 56 days, 90 days, 180 days and 365 days. Concrete with sand only and with cementitious materials (GP0) could get a qualitative strength of $39 \mathrm{MPa}$. There is an increase of $18.2 \%$ over the conventional concrete with $100 \%$ sand as a fine aggregate. The strength of concrete with $25 \%$ granite powder and $75 \%$ sand with cementitious materials (GP25) was estimated at $40 \mathrm{MPa}$ with an increase of $21.2 \%$ over conventional concrete[3] with $100 \%$ sand (CC). With other percentages of the addition of granite powder with the quantity of cementitious materials remaining the same the strength of concrete decreased. 
A. Arivumangai et al., International Journal of Emerging Trends in Engineering Research, 9(4), April 2021, $357-360$

Table 1: Strength of Rebound Hammer Values for M30 Concrete (MPa)

\begin{tabular}{|c|c|c|c|c|c|c|}
\hline $\begin{array}{c}\text { Replacemen } \\
\text { t Level }\end{array}$ & $\begin{array}{c}\text { Total No. } \\
\text { of } \\
\text { Specimen } \\
\text { s }\end{array}$ & $\begin{array}{c}\mathbf{2 8} \\
\text { Days }\end{array}$ & $\begin{array}{c}\mathbf{5 6} \\
\text { Days }\end{array}$ & $\begin{array}{c}\mathbf{9 0} \\
\text { Days }\end{array}$ & $\begin{array}{c}\mathbf{1 8 0} \\
\text { Days }\end{array}$ & $\begin{array}{c}\mathbf{3 6 5} \\
\text { Days }\end{array}$ \\
\hline GP0 & 15 & 39 & 42 & $\begin{array}{c}44.6 \\
5\end{array}$ & $\begin{array}{c}46.2 \\
5\end{array}$ & 49 \\
\hline GP25 & 15 & 40 & 44.2 & 48 & 51 & 53 \\
\hline GP50 & 15 & 38.2 & 41.9 & 44 & 46.6 & 48 \\
\hline GP75 & 15 & 37 & 40 & 42 & 44 & 46 \\
\hline GP100 & 15 & 35.7 & 39 & 42.5 & 45 & 47 \\
\hline NA100 & 15 & 35 & 38.6 & 42.2 & 43 & 45 \\
\hline CC & 15 & 33 & 35 & 39 & 40.9 & 43 \\
& & & 5 & 5 & \\
\hline
\end{tabular}

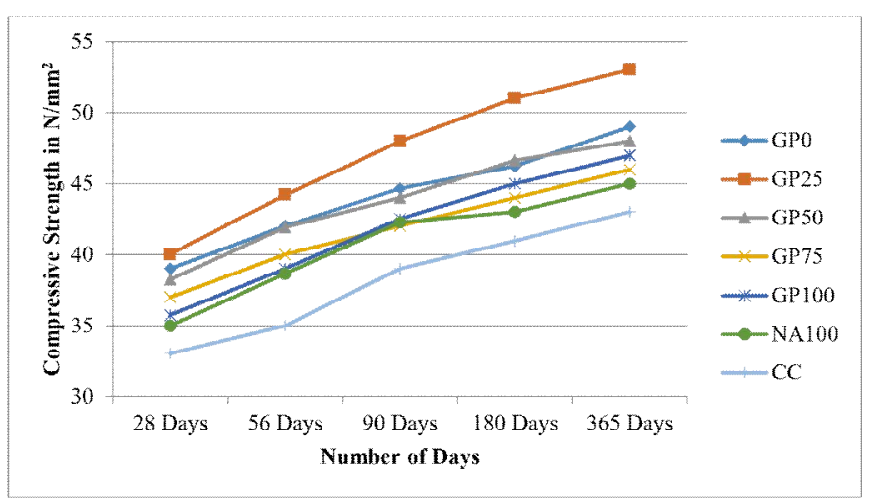

Figure 2: Strength of Rebound Hammer Test for M30 Concrete

In the case of M60 grade concrete the strength of conventional concrete (CC) was assessed as $66.80 \mathrm{MPa}$ at 28 days. Corresponding estimated strength of NA100 concrete was $62 \mathrm{MPa}$, a decrease in strength of $7.2 \%$ over the CC concrete. This shows that mere addition of granite powder without admixtures is not able to increase the strength of concrete for all ages of 56 days, 90 days, 180 days and 365 days, especially in the case of high-performance Concrete. The estimated strength of GP0 concrete was $68 \mathrm{MPa}$. There is an increase of $1.8 \%$ over CC concrete.

In the case of GP25 concrete the estimated strength was 70 $\mathrm{MPa}$ which is $4.8 \%$ greater than the CC concrete. The assessed strength in respect of concrete with the addition of other percentages of granite powder and admixtures decreased with the increase in percentages of these materials.

Table 2: Strength of Rebound Hammer Values for M60 Concrete (MPa)

\begin{tabular}{|l|c|c|c|c|c|c|}
\hline $\begin{array}{c}\text { Replacement } \\
\text { Level }\end{array}$ & $\begin{array}{c}\text { Total No. } \\
\text { of } \\
\text { Specimens }\end{array}$ & $\begin{array}{c}\mathbf{2 8} \\
\text { Days }\end{array}$ & $\begin{array}{c}\mathbf{5 6} \\
\text { Days }\end{array}$ & $\begin{array}{c}\mathbf{9 0} \\
\text { Days }\end{array}$ & $\begin{array}{c}\mathbf{1 8 0} \\
\text { Days }\end{array}$ & $\begin{array}{c}\mathbf{3 6 5} \\
\text { Days }\end{array}$ \\
\hline GP0 & 15 & 68 & 70.8 & 73 & 75 & 77 \\
\hline GP25 & 15 & 70 & 72 & 74.25 & 75.7 & 79 \\
\hline GP50 & 15 & 67 & 69 & 71.25 & 73 & 75.7 \\
\hline GP75 & 15 & 66 & 68.2 & 70 & 72 & 74 \\
\hline GP100 & 15 & 65.8 & 68 & 70 & 71 & 73.5 \\
\hline NA100 & 15 & 62 & 64 & 66 & 67 & 70 \\
\hline CC & 15 & 66.8 & 70.2 & 73 & 74.8 & 76.5 \\
\hline
\end{tabular}

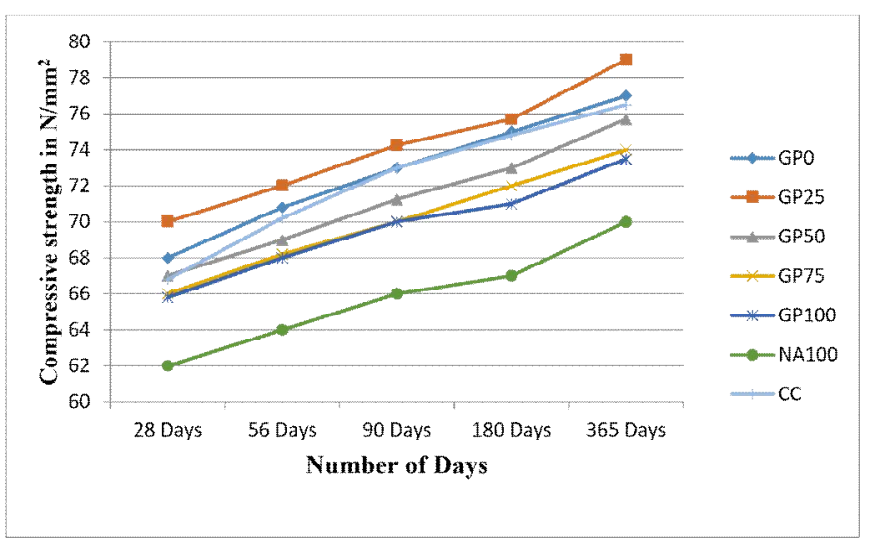

Figure 3: Strength of Rebound Hammer Test for M30 Concrete

The normal concrete (CC) in the case of M30 grade with $100 \%$ sand as fine aggregate and without granite powder as well as cementitious admixtures has attained a value of 35 MPa as against $33 \mathrm{MPa}$ obtained by Schmidt Hammer test 
A. Arivumangai et al., International Journal of Emerging Trends in Engineering Research, 9(4), April 2021, $357-360$

indicating close agreement between both values whereas that contained $100 \%$ granite powder (NA100) without sand, and cementitious materials has registered a compressive strength of $36 \mathrm{MPa}$ as against $35 \mathrm{MPa}$ obtained from non-destructive test. This shows that addition of granite powder to concrete has a distinct advantage of enhancing the strength of conventional concrete by $2.86 \%$. A similar increase in strength in both concretes was also observed at different ages, viz, 56 days, 90 days, 180 days 365 days in the case of M30 grade.

\section{REFERENCES}

1. Indian standard code of practice for "Non-destructive testing of concrete-Method of test (Rebound hammer)", I.S. 13311 (Part 1, 1992) Bureau of Indian standard (BIS).

2. Indian standard code of practice for "Method of test of strength of concrete", I.S. 516 (1959) Bureau of Indian standard.(BIS).

3. A. Arivumangai and T. Felixkala, "Strength and durability properties of granite powder concrete", J. Civ. Eng. Res. vol. 4, no.2A, pp.1-6, 2014.

4. M. Vijayalakshmi, A.S.S. Sekar and G. Ganesh Prabhu, "Strength and durability properties of concrete made with granite industry waste", Constr. Build. Mater. vol.46, no.1, 2013.

5. K.C. Reddy, Y.Y. Kumar and P. Poornima, "Experimental study on concrete with waste granite powder as an admixture", Int. J. Eng. Res. Appl. vol.5, no.87, 2015. 